\title{
Rabbâni Gelenekte Rabbi Yişmael'in Tevrat Tefsiri İçin Oluşturduğu On üç Yorum Kuralı
}

\author{
Dr. Ömer Faruk ARAZ*
}

Öz: Rabbâni Yahudilik, M.S. 70 yılında Yahudi Mabedinin ikinci kez yıkımı sonrasında, Mabet'e bağlı dinî yaklaşım ve uygulamaların ortadan kalkması ve bunun yerini Yahudi Kutsal Kitabı ile onun yorumlarının aldığ 1 dönemin adıdır. Bu sebeple Rabbâni Yahudiliğin temelini $\mathrm{TaNaH}$ ve yorumu oluşturmaktadır. Rabbâni Yahudiliğe göre Tanrı Sina'da Hz. Musa'ya Tora ile birlikte onun yorum kuralları ve bunlara uygun yapılan yorumlarını da vermiştir. Bu sebeple rabbiler tarafından yapılan bu yorumlar ilahi vahyin bir parçasıdır. Rabbâni Yahudilikte Hillel'e izafe edilen yedi yorum kuralı (middot), alanında ilk basamaktır ve kendisinden sonra geliştirilen diğer yorum kurallarının temeli ve öncüsüdür. Rabbi Yişmael on üç yorum kuralını R. Hillel'in yedi yorum kuralını geliştirerek elde etmiştir. Hatta onun bazı kuralları Hillel'in kurallarıyla birebir aynıdır. R. Yişmael'e izafe edilen on üç yorum kuralı Rabbâni Yahudilik için çok daha merkezî bir role sahip,tir. Ancak yorum kurallarının kökeni, kullanılması ve liste haline getirilmesiyle ilgili çeşitli tartışmalar da bulunmaktadır.

Anahtar Kelimler: Yişmael, Middot, Rabbâni, Çift Tora, Yahudilikte Yorum Kuralları

In Rabbinic Tradition, The Thirteen Interpretation Rules Compiled by Rabbi Yişmael for the Exegesis of Torah

Abstract: Rabbinic Judaism is name of the understanding that after the destruction of the Second Temple at A.D. 70, the disappearance of religious approaches and practices related to the Temple, and to replace them the TaNaH and its interpretation. Therefore, the $\mathrm{TaNaH}$ and its interpretation constitutes the basis of Rabbinic Judaism. According to Rabbinic Judaism, on Mount Sinai God has revealed Torah and its interpretation and the rules which rabbis interprets Torah depending on those rules. Therefore, interpretations made by the rabbis are a part of divine revelation. In rabbinic Judaism, seven hermeneutic rules (middot) which attributed to Hillel are the first step in its field, and the basis and pioneer the other rules which developed after them. R. Yişmael has been achieved his thirteen hermeneutic rules by developing on the seven hermeneutic rules of Hillel. In fact, some rules of R. Yişmael are exactly the same as the rules of R. Hillel. Thirteen hermeneutic rules which attributed to Yişmael has a much more central role in Rabbinic Judaism. However, there are also several discussions regarding the origin of hermeneutic rules, their using and creating them into the list.

Keywords: Yişmael, Middot, Rabbinic, Dual Torah, Hermeneutic Rules in Judaism

* Milli Eğitim Bakanlığı, ustadomer@gmail.com 


\section{Giriş: Rabbi Yişmael Öncesi Rabbâni Yorumun Genel Durumu}

Yahudilik tarih boyunca farklı devirlerde ortaya çıkan özelliklerine göre değişik şekillerde tanımlanmıștır. Bu bağlamda Mabet Öncesi Kutsal Kitap Dönemi Yahudiliği, I. Mabet Dönemi Yahudiliğii, II. Mabet Dönemi Yahudiliği, Rabbâni Yahudilik, Orta Çağ Yahudiliği ve Modern Dönem Yahudiliği biçimindeki tanımlamalarda dönemin siyasi, sosyal, kültürel ve dini şartlarına göre Yahudiliğin farklı özellikleri ön plana çıkarılmaktadır. Mabet öncesi dönemde Yahudi toplumunun yapısı ve dini öncelikleri ile I. ve II. Mabet dönemlerindekiler birbirinden farklıdır. ${ }^{1}$ Özellikle II. Mabet döneminde Yahudi toplumunun ve dini yaşamının merkezinde Mabet ve buna bağlı görev yapan kohen ${ }^{2}$ denilen din adamları ile onların öncülügüunde icra edilen kurban ibadeti yer alıyorken, M.S. 70 yılında II. Mabet'in yıkımı sonrasında gelişen Rabbâni Yahudilikte ise $\mathrm{TaNaH}^{3} \mathrm{1}^{3}$ merkeze alarak, hayatın her alanı ile ilgili $r a b b i^{4}$ denilen din adamları tarafından yapılan çeşitli yorumlar ön plana çıkmaktaydı. Rabbiler bu yorumlarını Sina'da Musa'ya Tanrı tarafından vahyedilen Tora'nın bir parçası olarak değerlendiriyorlar ve sunuyorlardı. Zamanla Yahudiliğin ana omurgası haline gelen bu yaklaşıma göre $\mathrm{TaNaH}$ 'n zahirde görünen anlamından çok daha derin manaları olduğu gibi, TaNaH’’n ilahi vahyin ürünü olmasının doğal sonucu olarak her türlü hatadan münezzeh olduğu kabul edilmektedir. Ayrıca Kutsal Kitap’ta zahiren birbiriyle çelişkili gibi görünen kısımlar bulunabilir. Ancak bu durumların hepsi makul bir şekilde izah edilebilir. Bu sebeple $\mathrm{TaNaH}$ ’n her bir cümlesi, kelimesi ya da harfi büyük bir dikkatle ve titizlikle ele alınarak izah edilmeye çalışılmalıdır. ${ }^{5}$

Mabet'in ortadan kalkması sebebiyle Mabet ve kurban ibadetinin yerini $\mathrm{TaNaH}$ çalışmalarının ve yorumunun aldığı Rabbâni Yahudiliğin en temel özelliklerinden birisi, $\mathrm{Ta}$ $\mathrm{NaH}$ metinlerinin "middot" denilen ve bu devirlerde sistematik hale getirilmeye başlanan yorum prensiplerine dayanılarak açıklanmasıdır. M.Ö. I.yy’n ikinci yarısında Yahudilerin $\mathrm{TaNaH}$ 'n yorumlanması faaliyetinde kullandıkları belli kurallara sahip olduğu genel olarak kabul edilmekle birlikte, bu kuralların bir sistem içerisinde düzenlenerek bir kurallar listesi haline ne zaman getirildiği hususu tam olarak bilinememektedir. ${ }^{6}$ Çeşitli yorumla-

1 Louis Jacobs, “Judaism”, EJd² (Encyclopaedia Judaica), XI, 514-517.

2 Kohen: Çıkış Kitabı 28 ve 29. Bablarda genel olarak anlatıldığı üzere İsrailoğullarına dini konularda rehberlik yapmaları için Rab tarafından seçilmiş olan, Harun ve soyundan gelen din adamları sınıfına verilen isimdir. Ayrıntılı bilgi için bk. Joseph Jacobs, “Cohen”, JE (The Jewish Encyclopaedia), IV, 144.

3 Tanah: Tora, Neviim ve Ketuvim kelimelerinin ilk harflerinin alınması ile olușturulmuș akrostiș bir kelime olarak Yahudi Kutsal Kitabını ifade etmek için kullanılmaktadır. Kelime kaynaklarda kutsal kitabın üç bölümünü temsil eden harfler büyük yazılması suretiyle “TaNaH” şeklinde de kullanılmaktadır. Yahudi Kutsal Kitabını ifade etmek için İslami kaynaklarda kullanılan Ahdi Atik, Eski Ahit gibi ıstılahlar Hıristiyan kökenlidir. Yahudi Kutsal Kitabı için Kuranda Tevrat, Kitab, Zikir gibi kelimeler kullanılmaktadır. Ayrıntılı bilgi için bk. Ömer Faruk Harman, "Ahd-i Atik”, DİA (Türk Diyanet Vakfi İslam Ansiklopedisi), İstanbul 1988, I, 494-501.

4 Rabbi kelimesi İbranice kökeni itibarıyla "rab, efendi, üstad" anlamlarına gelen "rav" (רב) kelimesinden gelmektedir. Kelime Kitab-1 Mukaddes İbranicesinde ise "büyük ya da seçkin" anlamına gelmektedir. Rabbâni Yahudiliğin en temel eserleri arasında yer alan Mişna ve Talmud'da görüşleri aktarılan din adamlarına verilen bir unvandır. Ayrıntılı bilgi için bk. Francis Brown, S.R. Driver, C.A. Briggs, Hebrew and English Lexicon of The Old Testament, New York 1906, s.912-913. Ayrıca bk. Louis Isaac Rabinowitz, "Rabbi, Rabbinate”, EJd², XVII, 11; Isaac Broydé, "Rabbi", JE, X, 294.

5 James Kugel, Traditions of the Bible: A Guide to the Bible as it Was at the Start of the Common Era, Cambridge 1998, s. 14-19.

6 Gary G. Porton, "Rabbinic Midrash", Judaism in Late Antiquity Part I The Literary \& Archaelogical Sources, ed. Jacob Neusner, Leiden 1995, s. 226. 
ma faaliyeti babından olmak üzere Sina vahyinden daha önceki zamanlarda gerek Yahudi toplumu içerisinde, gerek bölgede yaşayan diğer topluluklar arasında rüya ve kehanet yorumlarına rastlanılsa da, ${ }^{7}$ Tora'nın yorumlanmaya başlanması ile birlikte bunların Tora yorumunda kullanıldığını kolaylıkla ifade etmek mümkün değildir. ${ }^{8}$ Bu sebeple yorum kurallarına bağlı olarak sistematik bir tarzda yapılan rabbâni TaNaH yorum faaliyetinin, Yahudi geleneği içerisinde "ikili” anlamına gelen ve Yahudi cemaatini yöneten en önemli iki makamı ifade etmek için kullanılarak $Z u g o t^{9}$ adı verilen rabbi gruplarının son halkasında yer alan Hillel'e $\mathrm{e}^{10}$ (ö. ms. 20-30) izafe edilen yedi yorum prensibiyle başlatıldı̆̆ı söylenebilir. ${ }^{11}$ Hillel'den yaklaşık bir asır sonra yaşamış olan ve aşağıda maddeler halinde açıklayacağımız, Rabbi* Yişmael'e (ö. ms. 135) izafe edilen on üç yorum prensibiyle bu liste daha da genişletilmiştir. Bir nesil sonra ise R. Yişmael'in muasırı ve en önemli rakibi R. Akiva’nın (ö. ms. 135) talebelerinden olan R. Eleazar b. Yose ha-Galili’ye ${ }^{12}$ (ö. ms. 2.yy’ın sonları) izafe edilen otuz iki yorum prensibinin, çoğunluğu özellikle hagadik metinlerde kullanılsa da, Rabbâni Yahudiliğin $\mathrm{TaNaH}$ yorum sistemi içerisinde bu prensiplerin gelişim çizgisinin en geniş halini temsil ettiği söylenilebilir. ${ }^{13}$

Rabbâni Yahudilikte $\mathrm{TaNaH}$, yorumu ve bu yoruma dayanak teşkil eden yorum kuralları tamamıyla ilahi vahiy ürünü kabul edilerek, Hz. Musa'ya Sina dağında Tanrı’nın İsrail ve diğer tüm insanlık için vahyettiği Tora'nın hem yazılı hem de şifahi biçimde verildiği; şifahi kısım Yazılı Tora'nın yorum metotlarını, bu metotlar kullanılarak yapılan yorumları ve

7 * Rabbi kelimesi isimlerin önünde kullanıldığında çalışma boyunca “R." şeklinde kısaltılacaktır.

Manfred Oeming, Biblical Hermeneutics: An Introduction, terc. Joachim F. Vette, England 2006, s. 9-11.

8 Saul Lieberman, "Rabbinic Interpretation on Scripture", Hellenism in Jewish Palestine: Studies in the Literary Transmission, Beliefs and Manners of Palestine in the I Century BCE-IV Century CE, New York 1962, s.58.

9 Zugot (זוגות), kelime olarak "çift, ikili, ikişerli" anlamlarına gelmekte olup " $z u g$ " (זוג), kelimesinin çoğul halidir. Birisi siyasi lider/nasi, diğeri cemaat mahkemesi başkanı/av bet din olarak görev yapan; yaklaşık olarak M.Ö. 170 yıllarından itibaren Sadık Şim’on'un talebesi Soho'lu Antigonus'tan Şifahi Tora ve rivayetleri alıp aktararak bir buçuk asır boyunca görev yapan beș grup din adamını ifade etmektedir. Bu dönemin genel özellikleri ve ekolleriyle ilgili ayrıntılı bilgi için bk. Jacob Newman, Halahik Sources: From the Beginning to the Ninth Century, Leiden 1969, s. 14-15; Lawrence H. Schiffmann, From Text to Tradition: A History of Second Temple and Rabbinic Judaism, New Jersey 1991, s.182; Alexander Guttman, Rabbinic Judaism in the Making, Detroit 1970, s. 59-94; H.L. Strack- G. Stemberger, Introduction to the Talmud and Midrash, terc. Marcus Bockmuehl, Edinburg 1991, s. 70-71; Jacob Z. Lauterbach, "Zugot”, JE, XII, 698; Ömer Faruk Araz, Yahudilikte Midraşik Literatürün Tarihsel Gelişimi, Yayınlanmamış Doktora Tezi, Marmara Üniversitesi SBE, İstanbul 2016, s.100-106. Zugot halkasında yer alan rabbilerin çalıșmaları, rivayetleri ve onlara izafe edilen görüşlerle ilgili ayrıntılı bilgi için ayrıca bk. Jacob Neusner, The Rabbinic Traditions About The Pharisees Before 70, Leiden 1971, I, 60-338.

10 Hillel'in hayatı ile ilgili Yahudi kaynaklarında pek çok bilgi yer almakla birlikte bunların büyük çoğunluğu efsanevi karakterdedir. Ayrıntılı için bk. Yehoshua Horowitz, "Hillel”, EJ, IX, 108-110; Wilhelm Bacher, "Hillel”, JE, VI, 397; Judah Goldin, "Hillel the Elder", The Journal of Religion, vol.26, no.4, Oct., 1946, s. 263; Nahum N. Glatzer, Hillel the Elder: The Emergence of Classical Judaism, New York 1956, s. 24-25; Strack-Stemberger, Introduction to the Talmud and Midrash, s. 71.

11 Hillel’e izafe edilen bu kurallarla ilgili ayrıntılı bilgi için bk. Ömer Faruk Araz, "Rabbani Yahudiliğin İlk Yorum Prensipleri: Hillel'in Yedi Yorum Kuralı”, İnsan ve Toplum Bilimleri Araştırmaları Dergisi, c.5, sayı 2, 2016, s. 321 -337.

12 Yose ha-Galili’nin hayatı ile ilgili ayrıntılı bilgi için bk. Solomon Schechter- S. Mendelsohn, "Eliezer ben Jose haGelili", JE, V, 117.

13 Isidore Epstein, "Foreword", Midrash Rabbah, ed. H. Friedman- M. Simon, London 1939, s. xvi; W.Sibley Towner, "Hermeneutical Systems of Hillel and the Tannaim: A Fresh Look", Hebrew Union College Annual 53 (1982), s. 111; Moses Mielziner, Introduction to the Talmud: Historical and Literary Introduction, Cincinnati and Chicago 1894, s. 123-124; Louis Jacobs- David Derovan, "Hermeneutics", EJd', IX, s.25; Ömer Faruk Harman, "Yahudilik", DİA, XLIII, 199. 
ilave bazı öğretileri kapsadı̆̆ı belirtilmiştir. ${ }^{14}$ Rabbâni gelenekte Yazılı Tora "Tora şe-Bihtav"

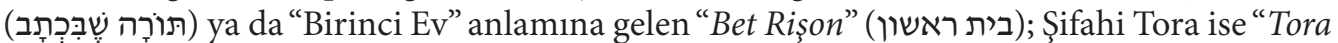
şe-be al Pe” (תורה שבעל פה) veya "İkinci Ev" anlamındaki “Bet Şeni” (בית שני) şeklinde ifade edilmiştir. ${ }^{15}$

Rabbâni Yahudilikte Sina'da Musa’nın aldı̆̆ı kabul edilen vahyin kapsamının çok geniş olduğu kabul edilmiştir. Buna göre Sina'da Tora'ya ${ }^{16}$ ilaveten Mişna $^{17}$, Hagada $^{18}$ ve Talmud'u, hatta iyi eğitimli öğrencilerin gelecekte hocalarına sormaları mukadder olan 'Tanrı kendini Musa'ya gösterdi mi’ gibi soruların cevaplarının bile Musa’ya vahyolunduğu ifade edilmiştir. ${ }^{19}$ Musa tarafından Sina'da bir bütün halinde vahiy olarak alınan Tora'nın yazılı biçimi $\mathrm{TaNaH}$ ile ortaya çıkarken, şifahi boyutu ise Yahudi dini geleneği içinde var olageldiği $;^{20} \mathrm{~Hz}$. Musa'dan itibaren sırasıyla Harun, Yeşu ve devamında hocadan talebesine nesiller boyu aktarılarak geldiği, nihayetinde rabbiler tarafından oluşturulan Mişna, Tosefta, Barayta'lar ${ }^{21}$, Kudüs Talmudu, Bâbil Talmudu ve Midraş Literatürü²2 gibi dokümanlarda kayıt altına alın-

14 Ephraim E. Urbach, The Sages Their Concepts and Beliefs, Jerusalem 1975, s.290-291; Jacob Neusner, “The History of Earlier Rabbinic Judaism: Some New Approaches”, History of Religions, 16:3, 1977: Feb, s.216; Philip R. Davies, "Judaism and the Hebrew Scriptures", ed. Jacob Neusner and Alan Avery-Peck, The Blackwell Companion to Judaism, USA 2004, s. 52; (Tora'nın yazılı ve şifahi boyutlarının aslında bir bütün halinde tek Tora olarak görülmesi gerektiği ile ilgili olarak bk. Jacob Neusner, Invitation to Midrash, s. 7; Ayrıca bk. Jacob Neusner, "Midrash and the Oral Tora: What Did the Rabbinic Sages Mean by 'The Oral Tora”, The Encyclopaedia of Judaism, ed: Jacob Neusner, Alan J. Avery-Peck, William Scott Green, Leiden 2005, III, s. 1708. (Sina vahyinin TaNaH ve Kuran-1 Kerim’e göre değerlendirilmesi ve bu konudaki farklı değerlendirmeler için ayrıca bk. Mustafa Sinanoğlu, "Eski Ahit ve Kur'an-1 Kerim'de Sina Vahyi", İslam Araştırmaları Dergisi, sayı 2, 1998, s. 1-22).

15 Neusner, Introduction to Rabbinic Literature, s.5; Susan A. Handelman, The Slayers of Moses, The Emergence of Rabbinic Interpretation in Modern Literary Theory, New York 1982, s. 41-42. Buradaki birinci ve ikinci şeklindeki isimlendirmenin öncelik ve ehemmiyet anlamı değil de sadece vahyin iki başlangıç noktasını kastettiği belirtilmiştir. (Şifahi Tora'nın çeşitli kaynaklarda değişik anlamlarda kullanıldığı, buna göre en az beş anlama geldiği ifade edilmiştir. Konuyla ilgili ayrıntılar için bk. Mehmet S. Toprak, Talmud ve Hadis, İstanbul 2012, s. 58-59)

16 Sina'da vahyedilen Tora'dan bahsedildiğinde tam olarak ne kastedildiği ile ilgili ayrıntılı değerlendirmeler için bk. Shaye J. D. Cohen, “The Judean Legal Tradition and the Halakhah of the Mishnah", The Cambridge Companion to The Talmud and Rabbinic Literature, (ed.) Charlotte Elisheva Fonrobert, Martin S. Jaffee, New York 2007, s. 121-123.

17 Mişna: Yahuda ha-Nasi tarafından miladi 2.yy’ın sonlarında derlendiği kabul edilen, altı ana bölüm, altmış üç alt bölümden oluşan Rabbâni literatürün ilk yazılı ürünüdür. Ayrıntılı bilgi için bk. Stephen G. Wald, "Mishnah” EJd², XIV, 319-331.

18 Hagada: Rabbâni geleneğin dini hüküm içeren halakik kısımları dışında kalan, daha çok rivayet ve menkıbevi boyuttaki rivayetlere verilen isimdir. Ayrıntılı bilgi için bk. Stephen G. Wald, "Aggadah or Haggadah" EJd², I, 454.

19 Yeremya Kitabı 23/29'da "Benim sözüm ateş gibi, ve kayaları paralayan külünk gibi değil mi? diyor Rab." cümlesi yer almaktadır. Bu ifadenin yorumunda bir çekiç kayaya vurulduğunda kayayı pek çok parçaya ayırdı̆̆ı gibi bir cümle de pek çok anlama sahip olabileceği belirtilmiş olup bir başka kaynakta ise her bir kelimenin en az yetmiş anlamı olduğu ifade edilerek, zikredilen yetmiş sayısının sonsuz sayıdan kinaye olduğu belirtilmektedir. Soferim bu anlamları izah etmeye çalışmaktadır. Ayrıntılı bilgi için bk. Handelman, The Slayers of Moses, s. 67. Ayrıca bk. Man Ki Chan, A Comparative Study Of Jewish Commentaries And Patristic Literature On The Book Of Ruth, Yayınlanmamış Doktora Tezi, University of Pretoria, South Africa 2010, s. 125.

20 Neusner Musa'ya Sina'da Tanrı tarafından verilen Tora'nın üç kısım olduğunu ifade eder. Rabbâni literatür, Tanrı'nın İsrail'e vahyi olan Tora'nın önemli bir parçası olarak görülür. Ancak bu literatür Tora'nın sadece bir kısmını oluşturmaktadır. Neusner'e göre Tora’nın birinci kısmı "Yazılı Tora” denilen Kutsal Kitap; ikinci kısım Şifahi Tora olup ilk olarak yaklaşık M.S. II. yy’da yazıya geçirilen Mişna ve diğer rabbâni literatür tarafından temsil edilir. Üçüncü kısım ise "rabbi" olarak isimlendirilen ve Musa paradigmasının tecessümü ve temsilcisi olan din adamlarının yorumlarıdır. Ayrıntılı bilgi için bk. Neusner, Introduction to Rabbinic Literature, s. 5; Ayrıca bk. Neusner, "Midrash and the Oral Tora: What Did the Rabbinic Sages Mean by “The Oral Tora”, s. 1712-1714.

21 Mişna tarzında kaleme alınsalar da Mişna içinde yer verilmeyen rivayetlere "Barayta" adı verilir.

22 Midraş literatürü, Ezra döneminde Tora'nın halka açıklanması faaliyeti ile başlayan, sinagog ibadeti ve vaazlar yoluyla ilerleyen, Mabet'in yıkılması sonrasında TaNaH’ın anlaşılması ve Yahudiliğin yaşanması konularında 
dığg kabul edilmektedir. Bu derlemelerde şifahi geleneğin orijinal olarak muhafaza edildiğine inanılmaktadır. ${ }^{23}$

Rabbiler önceki nesillerden hocaları kanalıyla tevarüs ettikleri dini bilgi ve rivayetleri Şifahi Tora olarak görüp bunları Yazılı Tora'yla aynı vahiy kaynağına rücu ettirerek kendilerine kadar aktarıla gelen öğreti, gelenek, rivayet ve yasalara kutsal bir statü kazandırmışlardır. Buna göre Rabbâni Yahudiliğin düşünce, fikir ve bunların yer aldığ literatürün meşruiyet zeminini Sina vahyine yüklenen anlama bağlı olarak Çift Tora İnancı'nın oluşturduğu ifade edilebilir. ${ }^{24}$ Rabbâni Yahudiliğin vahiy görüşünü özetleyen bu yaklaşım, onların kutsal metinlerin yorumuna yönelik genel perspektiflerini de yansıtmaktadır. Buna göre yazılı vahye ilaveten bu vahyin kendileri vasıtasıyla yorumlandığı kurallar (middot) ve bu kurallar kullanılarak üretilen yorumlar tamamıyla vahiy şemsiyesi altında değerlendirilmiştir. ${ }^{25}$

\section{R. Hillel ve R. Yișmael'in Yorum Kuralları Listelerinin Mukayesesi}

Rabbâni Yahudilik içerisinde yorum kuralları listesinin ilk halkasını Hillel’e izafe edilen yedi kural oluşturmaktadır. Bununla birlikte Hillel'e nazaran daha geniş bir liste halinde olan Yişmael'in on üç yorum kuralı, kendisinden önceki kurallardan bağımsız bir şekilde tamamen yeni prensipler ortaya koymamaktadır. R. Yişmael'e izafe edilen "On üç Middot" listesi, aslında Hillel'in listesinin iki noktada genişletilmiş halidir. Hillel'in beşinci kuralı "Kelal u-Perat, u-Perat u-Kelal” Yişmael'in sisteminde "Kelal u-Perat, Perat u-Kelal, Kelal u-Perat u-Kelal” şeklinde üçe ayrılmış; ayrıca bunlara aynı prensibin ilave beş biçimi eklenmiştir. Genişletmeye ilaveten Yişmael'in listesinde yeni olarak on üçüncü kural eklenmiştir. ${ }^{26}$

hayatî rol oynayarak akademilerdeki eğitimin önemli bir parçası olarak gelişen, TaNaH’’n kendine özgü uygulama kuralları ile açıklanması, yorumlanması ve bu yorumların bir araya getirilmesiyle oluşan literatürdür. Ayrıntılı bilgi için bk. Araz, Yahudilikte Midraşik Literatürün Tarihsel Gelişimi, s. 52.

23 Fraade, Steven D., “The Early Rabbinic Sage”, The Sage in Israel and the Ancient Near East, (ed.) John G. Gammie Leo G. Perdue, Indiana 1990, s. 419-420. Şifahi Tora’nın, Musa'dan başlayarak Bâbil Talmudu'nun tamamlanışındaki son râviye kadar uzanan kesintisiz bir rivayet zinciri "şalşelet ha-kabala" (שלשלת הקבלה) ile nakledilmiş olduğu, rabbiler tarafından iddia edilmektedir. Bu silsile kesintisiz bir zincir şeklinde Musa'dan başlamak kaydıyla önce nesiller şeklinde, M.Ö. II.yy'dan itibaren M.S. 70 yılına kadar devam eden rabbi isimlerinden oluşan liste halinde Avot Risalesi (Pirke Avot) birinci bölümde sıralanmıştır. Ayrıntılı bilgi için bk. Pirke Avot, terc. Rav Naftali Haleva, İstanbul: Gözlem Yayıncılık, 2004, s. 1-24.

24 Hindy Najman, Seconding Sinai: The Development of Mosaic Discourse in Second Temple Judaism, Boston, 2003, s.109-110; Michael Fishbane, The Garments of Torah: Essays in Biblical Hermeneutics, USA 1992, s. 121-125; Moritz Steinschneider, Jewish Literature from the Eighth to the Eighteenth Century: with an Introduction on Talmud and Midrash, terc. William Shotliswoode, London 1857, s.9; Neusner, "Midrash and the Oral Tora: What Did the Rabbinic Sages Mean by “The Oral Tora”, s. 1707-1708.

25 Israel Frankel, Peshat in Talmudic and Midrashic Literature, Toronto 1956, s. 46. Burada Tanrının kırk günde vahyin tüm yorumunu Musa'ya vermesinin yanında ona yorum kurallarını da verdiğiyle ilgili rabbâni literatürde yer alan bilgi aktarılmaktadır. Ayrıca bk. Bernard Rosensweig, "The Hermeneutic Principles and Their Application”, TRADITION: A Journal of Ortodox Thought, vol.13, no.1, Summer 1972, s. 49-50.

26 Towner, "Hermeneutical Systems of Hillel and the Tannaim: A Fresh Look", s. 125; Ayrıca bk. Zeitlin, "Hillel and the Hermeneutic Rules", s. 173; Handelman, The Slayers of Moses, s.52; Mielziner, Introduction to the Talmud ..., s. 126-128. 
İki listenin genel bir karşılaştırmasını tablo halinde şöyle gösterebiliriz:

\begin{tabular}{|c|c|c|}
\hline$\underline{\text { Sira No }}$ & $\underline{\text { HİLLEL }}$ & $\underline{\text { YISSMMAEL }}$ \\
\hline $1-$ & Kal va-Homer & 1- Aynı \\
\hline $2-$ & Gezera Şave & 2- Aynı \\
\hline $3-$ & Binyan Av mi-Katuv Ehad & \multirow{2}{*}{$\begin{array}{l}\text { 3- Hillel'in } 3 \text { ve } 4 \text {. kuralları tek kural olarak ele alın- } \\
\text { di. }\end{array}$} \\
\hline 4- & Binyan Av mi-Şney Ketuvim & \\
\hline $5-$ & Kelal u-Perat u-Perat u-Kelal & $\begin{array}{l}\text { 4- 11: Hillel'in } 5 \text {. kuralının genişletilmiş ve değiştiril- } \\
\text { miş şekilleridir. }\end{array}$ \\
\hline $6-$ & Kayotze bo mi-Makom Aher & Yişmael'in listesinde yer verilmemiştir. \\
\hline $7-$ & Davar ha-Lomed me-İnyano & $\begin{array}{l}\text { 12- İkinci bir cümle ilavesiyle Hillel'in } 7 \text {. kuralıyla } \\
\text { aynıdır. }\end{array}$ \\
\hline & & $\begin{array}{l}\text { 13- Şney Ketuvim ha-Makhişim ze et ze ad şe-Yavo } \\
\text { ha-Katuv ha-Şlişi va-Yakria Beynehem. }{ }^{27}\end{array}$ \\
\hline
\end{tabular}

\section{Rabbi Yişmael'in Yorum Kuralları}

Rabbi Yişmael'in 13 kuralı (middot) ile ilgili metin Tannaim dönemi ${ }^{28}$ midraşlarından R. Akiva Ekolüne ait olduğu düşünülen Sifra'nın başında bulunur. ${ }^{29}$ Bu kurallara Yahudilikte büyük önem atfedilir. Geleneksel rabbâni anlayışa göre Tora'nın yorumlanmasına yardımcı olan bu kurallar Musa’ya Sina’da vahyedilmiştir. ${ }^{30}$.

Geleneksel kabul bir tarafa R. Yişmael'in bu “middot”ların herhangi birinin kaynağı, ilk kullanıcısı olduğunu, hatta mevcut listenin düzenleyicisi olduğunu kolaylıkla iddia etmek mümkün değildir. Yalnızca geleneğin erken dönem rivayetlerinde on üç middot listesinden bahsedilmesinden dolayı; biz bu on üç kurallı listenin yedi kurallı liste kadar erken bir zamanda geliştirilmiş ve genellikle şu an sahip olduğumuz listeye benzeyen şekliyle tannaim döneminde bilindiğini varsayabiliriz. ${ }^{31}$

27 Towner, “Hermeneutical Systems ...”, s. 125-126; Ayrıca bk. Mielziner, Introduction to the Talmud..., s. 126-128.

28 Tannaim dönemi genel olarak Miladi ilk yıllardan başlayarak 220 yılı civarında Mişna’nın tedvini ile tamamlandığ 1 kabul edilen, Yahudiliğin şifahi kültürünün yazıya geçirilmeye başlandığı döneme verilen isimdir. Ayrıntılı bilgi için bk. Daniel Sperber, “Tannaim” EJ², XIX, 505; Jacob Z. Lauterbach, “Tannaim and Amoraim”, JE, XII, 49; Araz, Yahudilikte Midraşik Literatürün Tarihsel Gelişimi, s. 106-110.

29 Sifra, Baraita deRabbi Yişmael 1, 1-17. http://www.sefaria.org/Sifra, Braita d'Rabbi Yishmael.2?lang=heen\&layout=heLeft\&sidebarLang=all. (Erişim Tarihi: 20.02.2016).

30 Strack-Stemberger, Introduction to the Talmud and Midrash, s. 24; Ayrica bk. Lieberman, "Rabbinic Interpretation on Scripture", s. 54; Handelman, The Slayers of Moses, s. 41; Sicker, An Introduction to Judaic Thought and Rabbinic Literature, s. 31; Menahem Elon, "Interpretation", EJd', IX, 818.

31 Towner, "Hermeneutical Systems ...”, s. 126. 
Bu prensipleri şöyle izah edebiliriz:

\section{1- Kal va-Homer (קל וחומר):}

İbranice "kal" (קל) ağırlık bakımından hafif ve daha önemsiz olan, "homer" (חומר) ise öncekine göre daha ağır ve önem arz eden anlamına gelir. Terim olarak, hafif olandan ağır olanı yahut ağır olandan hafif olan ile ilgili sonuca ulaşma veya hüküm çıkarma demektir. Kal va-Homer yorum kuralı hem Hillel hem de Yişmael'in yorum sisteminde ilk sırada bulunur. Bu kural, yapılan çıkarımdan hareketle "hüküm vermek" anlamına gelen "din" (דין) ve Yud-Gimel Midot (ידות) adıyla da bilinir. Talmud tartışmalarında bu kural sıklıkla kullanilır. ${ }^{32}$

Kal va-Homer yorum kuralından şayet yasaya dair belli katı bir hüküm daha az önemli bir hususla alakalı olarak bulunursa, bu durumda bundan aynı hükmün önem açısından daha büyük olana uygulamaya daha layık olduğu sonucu çıkarılabilir. Ayrıca şayet daha önemli bir şey hakkında dini bir ruhsat verilmişse, biz aynı ruhsatın nispeten daha az önemli olana da orantılı olarak uygulanabilir olduğu hükmüne ulaşabiliriz. Mesela Şabat'in (Sebt/Cumartesi) belli yönleriyle dini bir festivalden daha önemli (חומר) olduğu kabul edilir. Buna göre şayet bir işe Şabat günü izin verilmişse, bu işe dini bir festivalde öncelikle izin verilebilir. Ayrıca şayet bir iş festivalde yasaklanmış ise, bunun Şabat gününde de yasaklanmış olması gerekir. ${ }^{33}$ Rabbiler bu prensibin TaNaH'ta kullanıldı̆̆ına işaret ederler. R.Yişmael de Tora'da on yerde bu prensibin kullanıldığını ifade eder: ${ }^{34}$ Yeremya Kitabı 12/5'te "Eğer yaya gidenlerle koştun da seni yordularsa, atlarla nasıl yarışabilirsin"; Tekvin Kitabı 44/8'de “Torbalarımızın ă̆zında bulduğumuz paraları Kenan ülkesinden sana geri getirdik. Nasıl efendinin evinden altın ya da gümüş çalarız?”; Çıkış Kitabı 6/12'de "Musa, "İsrailliler beni dinlemedikten sonra, firavun nasıl dinler?" diye karşılık verdi."; Tesniye Kitabı 31/27'de “Bugün ben sağken, aranızdayken bile RAB’be karşı geliyorsunuz; ölümümden sonra daha ne kadar çok başkaldıracaksınız." cümleleri bu kullanımlardan bazılarıdır. ${ }^{35}$

Kal va-Homer kuralı uygulaması şöyle gerçekleşmektedir: Şayet bir konuyu düzenleyen, daha az kesin olarak bilinen bir "A" yasası "Y" yi gerektiriyorsa daha kesin olduğu bilinen hükümler getiren "B" yasası da "Y"yi gerektirecektir. ${ }^{36} \mathrm{Bu}$ argümanın Aristo kıyasının İbranice versiyonundan farklılıkları vardır. Kıyasta eğer ilk önerme ile ikinci önerme doğru ise; cins ve türlerle ilgili bir hata yoksa sonuç zorunlu olarak doğru olur. Kal va-Homer'de sonuç aynı zorunlu yol ile ortaya konmaz. Çünkü mukayese edilen iki yapı aynı türden değildir. Bu sebeple mukayese genel terimlerle yapılmalıdır. ${ }^{37}$ Ayrıca kıyas isimlerle, Kal va-Homer ise cümle ile ilgilidir. Kıyasa göre "Tüm insanlar ölümlüdür. Sokrat insandır. Öyleyse Sokrat da ölümlüdür.” ifadeleri öncülleri ve sonucu oluşturur. Bu uygulamada en kilit

32 Mielziner, Introduction to the Talmud ..., s. 132; Ayrıca bk. Toprak, Talmud ve Hadis, s. 235-236.

33 Mielziner, Introduction to the Talmud ..., s. 130-131; Ayrica bk. Rosensweig, "The Hermeneutic Principles and Their Application", s. 51; Toprak, Talmud ve Hadis, s. 236.

34 Sifra, Baraita deRabbi Yişmael, 1; Ayrıca bk. Rosensweig, “The Hermeneutic Principles and Their Application”, s. 52; Elon, "Interpretation”, s. 819.

35 Bu kuralın uygulanması ile ilgili farklı örnekler ve açıklamalar için ayrıca bk. Araz, "Rabbani Yahudiliğin İlk Yorum Prensipleri: Hillel'in Yedi Yorum Kuralı”, s. 321-337.

36 Towner, "Hermeneutical Systems ..., s. 115.

37 Towner, "Hermeneutical Systems ...", s. 115; Ayrıca bk. ed. Emil Schürer, - Geza Vermes v. dğr., The History of the Jewish People in the Age of Jesus Christ (175 B.C. - A. D. 135), Edinburg 1979, s. 344. 
ifade Sokrat'ın insan sınıfına dâhil edilmesidir. Ancak Kal va-Homer'de en önemli adım atılırken sınıflar arası aidiyetten değil benzerliklerden hareket edilir. ${ }^{38}$

Kal va-Homer'in kullanıldığ 1 yer ve duruma göre bazı hususiyetleri vardır. Mesela dini uygulamalarla ilgili kullanılırken bir çıkarım ile elde edilen hukuksal sonucun orijinal yasanın şiddetini aşamayacağı ifade edilir. Bir diğer sınırlandırma ise bu kuralın ceza yasalarındaki uygulamalarındadır. Buna göre cezası küçük olan bir yasadan büyük olan bir yasaya yönelik bir çıkarım yapılamaz. ${ }^{39}$

\section{2- Gezera Şave (גזירה שווה):}

Kelime olarak benzer ifade, tabir ve tanımların benzerlikleri yönüyle mukayesesi anlamına gelmektedir. Bu kuralın tatbikinde mukayese edilecek şeylerin kıyasa elverir şekilde birbirine denk, alakalı-ilgili olması gerekir. Bunlardan hareketle Gezera Şave'nin iki benzer hükmün mukayese edilerek bir başka hükmün çıkarılmasını sağlayan yorum kuralı olduğu söylenilebilir. Talmud yorumlama sisteminde bu tür analoji iki şekilde uygulanır:

a) Hekkeş (Hikkiş): Hikkiş (היקש) kelimesi karşılaştırmak anlamına gelen "lehakîş" (להקיש) fiilinden gelmektedir. Talmudik terminolojide birbiriyle bağlantılı iki konunun Tora'nın bir cümle ya da pasajında geçen ve buradan hareketle çıkarılan hükmüyle ilgili yapılan bir tür analojiye işaret eder. ${ }^{40}$ Bunun Gezera Şave ile farkı şudur: Gezera Şave iki pasaj arasındaki benzerliklerle ilgili iken hikkiş, aynı pasajda bir ya da iki konunun yakın bağlantısına dayanan bir benzetmeyi ifade etmektedir. ${ }^{41}$

b) Gezera Şave (גזירה שווה):

Bu ismin etimolojisi ve gerçek anlamıla ilgili pek çok hipotez ileri sürülmüş olsa da, bugüne kadar tatmin edici bir açıklama yapılamamıştır. "gezera" ve "şave" olmak üzere iki kavramdan oluşan terimde "kesmek, karar vermek ve hüküm vermek" anlamlarına gelen "gazar" fiilinden gelen "gezera" kelimesi "karar veya ferman" anlamina gelmektedir. ${ }^{42} \mathrm{Bu}$ anlamı ile İbranice olarak TaNaH’ta kullanılmasa da Aramice olarak Daniel Kitabı 4/14, 21'de yer almaktadır. ${ }^{43}$ Terimi oluşturan diğer kelime olan "şave" ise "eşit, denk ve aynı" gibi anlamlara gelmektedir. ${ }^{44}$

Yahudi rabbâni geleneğinde Gezera Şave, TaNaH’taki aynı ifadelere dayanan iki yasa arasındaki benzerliği ifade etmektedir. Kişi Gezera Şave yoluyla bir yasanın hükmünün bir başkasına da uygulanabileceğini ortaya koyar. Bu kuralın rabbâni gelenekteki en önemli örneği Hillel'e yöneltilen Şabat'a tevafuk eden Pesah (Fısıh) kuzusu kurbanına izin verilip

38 Louis Jacobs- David Derovan, "Hermeneutics", s.25-26; Handelman, The Slayers of Moses, s. 53.

39 Handelman, The Slayers of Moses, s. 57; Ayrica bk. Strack, Stemberger, Introduction to the Talmud and Midrash, s. 21.

40 Mielziner, Introduction to the Talmud ..., s. 152-153; Louis Jacobs- David Derovan, "Hermeneutics", s.26; Toprak, Talmud ve Hadis, s. 241-242.

41 Handelman, The Slayers of Moses, s. 58; Louis Jacobs- David Derovan, "Hermeneutics", s. 26; Hikkiş ile ilgili ayrıntılı bilgi ve örnekler için ayrıca bk. Jochanan Zaqantov, "Plain Meaning and Analogy, Peshat ve Heqqesh", s. 1 vd., http://www.karaitejudaism.org/talks/Plain_Meaning_and_Analogy.pdf, (Erişim Tarihi: 15.09.2015); Mielziner, Introduction to the Talmud ..., s.152-155; Elon, "Interpretation", s. 820.

42 Francis Brown, S.R. Driver, C.A. Briggs, Hebrew and English Lexicon of The Old Testament, s. 160.

43 Daniel Kitab1 14/4".

44 Michael Gertner, “Terms of Scriptural Interpretation: A Study in Hebrew Semantics”, Bulletin of the School of Oriental and African Studies, 25, No.1/3, 1962, s. 24. 
verilmeyeceği sorusuna Hillel'in bu kuralı uygulayarak verdiği cevabıdır. Normalde böyle bir eylem Şabat yasağının kapsamına girer. Hillel, tamid denilen günlük sunu ile ilgili yasaya atıfta bulunarak (Sayılar Kitab1 28/2) burada kullanılan ${ }^{45}$ ve Pesah sunusundan bahseden Sayılar Kitabı 9/2'de yer alan6 "b'moado/במועדו" ifadelerinden hareketle cümleler arasında analoji yaparak Pesah kuzusu takdimesinin Şabat'ta icrasına hükmetmiştir. ${ }^{47}$

Bu kuralın kullanılması bir hükümdeki müphem bir hususun anlamını tayin etmeye yardımcı olabileceği gibi, bir hükme kıyasen bir başka hükmü çıkarmaya da yardımcı olabilir. $^{48}$

Gezara Şave’nin uygulanması hususunda bazı önemli noktalar vardır. Bir rabbi Gezera Şave'ye dair bir kuralı, kaynağı olmaksızın kendiliğinden ileri süremez; bunu mutlaka bir hocasından almak suretiyle geliştirmesi gerekir. Gezera Şave, hükmü belirsiz müphem olan bir hususun açık ve belirli, kesin olan bir başka hükümle izah edildiği yorumsal; ${ }^{49}$ veya ihmal edilen veya atlanan bir hükmü daha sarih olan bir başka hükümle sunma şeklinde, ilk defa Hillel tarafından ortaya konmuş yapısal uygulaması vardır. ${ }^{50}$ Özellikle Amoraim döneminden ${ }^{51}$ itibaren bu kuralın daha farklı kullanımları ve bu kullanımlara bağlı çeşitli tartışmalar ortaya çıkmıştır. Ayrıca Gezera Şave’nın özellikle halaha ile ilgili kullanımda her iki cümlede de anahtar bir kelimenin olması gerekse de hagada için aynı sınırlandırmalar yoktur. ${ }^{52}$

Gezera Şave metodunun R. Yişmael bir tarafa Hillel'den önce de kullanıldı̆̆ı, bu metodun Yahudiler tarafından Greklerden alındığına dair iddialar vardır. Ayrıca metodun kullanımı ile onun tanımlanması (terminolojisi) ve isimlendirilmesi iki ayrı husus olup bu

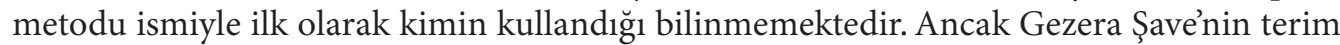
olarak M.S. I.yy'dan itibaren kullanılmış olması muhtemeldir. ${ }^{53}$

\section{3- Binyan Av mi-Katuv Ehad ve Binyan Av mi-Şney Ketuvim}

(בנין אב מכתוב אחד ובנין אב משני חכתובים):

Bu kuralı "bir veya iki cümla ya da pasajdan temel bir kural inşa etme" olarak tercüme edebiliriz. Bu kural Hillel’in listesinde iki ayrı prensip olarak ele alınmışken Yişmael

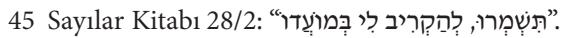

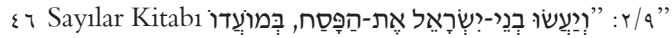

47 Handelman, The Slayers of Moses, s. 57-58; Gezera Şave ile ilgili Talmud'da yer alan başka örnekler için ayrıca bk. Rosensweig, "The Hermeneutic Principles and Their Application", s. 55-58; Hillel Ben David (Greg Killian), "Rules of Jewish Hermeneutics", s.4, http://www.betemunah.org/rules.html, (Erişim Tarihi: 04.06.2015); Zeitlin, "Hillel and the Hermeneutic Rules", s.167-168; Towner, "Hermeneutical Systems ...", s. 116-118.

48 Toprak, Talmud ve Hadis, s. 240.

49 Yorumsal Gezera Şave örnekleri için bk. Mielziner, Introduction to the Talmud ..., s. 143-144.

50 Mielziner, Introduction to the Talmud ..., s. 145-147; Ayrıca bk. Toprak, Talmud ve Hadis, s. 241.

51 Mişna’nın tedvini sonrası M.S. 220 yılı civarında başlayarak, 5.yy’ın sonuna kadar devam ettiği genellikle kabul edilen dönemdir. Bu devrin özellikleri ve edebi ürünleri ile ilgili ayrıntılı bilgi için bk. Alyssa M. Gray, "Amoraim”, EJd', II, 89-94; Baruch M. Bokser, “Amoraim”, Encyclopaedia of Religion (ER), I, 294-295; Araz, Yahudilikte Midraşik Literatürün Tarihsel Gelişimi, s. 131-143.

52 Mielziner, Introduction to the Talmud ..., s. 147-149; Lieberman, "Rabbinic Interpretation on Scripture", s.61-62; Handelman, The Slayers of Moses, s. 58.

53 Lieberman, "Rabbinic Interpretation on Scripture", s.61-62; Gary G. Porton, "Rabbinic Midrash", s.226; Manfred Oeming, Biblical Hermeneutics: An Introduction, s.9-11; David Daube, "Rabbinic Methods of Interpretation and Hellenistic Rhetoric", HUCA, 22 (1949), s.255-258. 
tarafından bir arada tek kural olarak değerlendirilmiștir. "Binyan Av" yasalar arasında mukayese edilebilirliği oluşturmak için bir araçtır. Özel bir durumla ilgili hükmün sebebinin umumî olmasından hareketle hükmün de umumi olması anlamındadır. ${ }^{54}$

Binyan Av’nn Tannaim döneminde uygulamasının bir örneği olarak Çıkış Kitabı 13/13’teki “Oğulların arasından insanların bütün ilk doğanları için fidye vereceksin." metniyle ilgili tartışmayı zikredebiliriz. Erken dönemlerde yapılan yorumlar "babasının fidye vermediği bir oğulun kendisinin fidye vermesinin gerektiğini' kanttlamaya çabalar. Bu cümle daha geniş pasajlarında zaten zikredilen diğer görevlerle bu görevin mukayesesi yapılarak özellikle sünnet (Çıkış Kitabı 12/48) ve eğitim (Çıkış Kitabı 13/8, 14/15) ile ilgili hükümlerle birlikte ele alınmıştır. Bu üç emirle ilgili tartışmalar onların önem olarak ne kadar farklı olduklarını ortaya koymaktadır. Tora’nın önemli bir emri olan babanın oğluna Tora öğretme görevi ve sünnet görevi yanında ilk doğanın fidyesinin verilmesi emri üçüncü derecede bir öneme sahiptir. Ancak üç emir de aşağıdaki argümana izin veren bir mukayese edilebilirlik zeminine sahiptir: ${ }^{55}$ Sünnet, ilim tahsili ve ilk doğan fidyesi emirlerinin her üçünde de yaygın olan şey her birinin baba tarafından oğula yönelik icra edilmesi gereken dini bir görev olmasıdır. Şayet baba bu görevi yerine getirmezse oğul bizzat yapmalıdır. $\mathrm{Bu}$ sebeple baba tarafından icra edilmesi gereken oğulla alakalı herhangi bir dini görevi baba yapmazsa bu görevin oğul tarafından yerine getirilmesi gerektiği sonucuna varılmaktadır. ${ }^{56}$

Metinde ele alındığı şekliyle Binyan Av argümanı şöyle işlemektedir:

1. Aşama: Hüküm ile ilgili bir dizi $\mathrm{TaNaH}$ emri incelendikten sonra yorumcu her üç örneği de kapsayan genel bir kural (binyan av) ortaya çıkarmak ister.

2. Aşama: Her bir emrin özel yönü ortaya çıkarılmaya çalışılır.

3. Aşama: Üç örneğin hepsini kapsayan bir ifade oluşturulur: 'Bunlardan her biri baba tarafından icra edilmesi gereken oğulla ilgili dini bir görevdir.'

4. Aşama: Bir emir için doğru sayılan bu yardımcı düşünceler mukayese edilebilir olan için de doğru sayılarak, üç emri aynı bağlam içerisinde mukayese yapmaya ve bu mukayeseden çıkarımda bulunmaya çalışılır.

5. Aşama: Mukayese ve çıkarım yoluyla ortaya konan bu "genel kural" sonuçta evrensel bir uygulama prensibi haline gelir. ${ }^{57}$

Binyan Av TaNaH’ın iki pasajı yoluyla da çıarılabilir. Örneğin Çıkış Kitabı 21/26 ve 27 'de bir kimsenin kölesinin gözüne ve dişine zarar vermesiyle ilgili hükümler vardır. ${ }^{58} \mathrm{Bu}$ cümlelerde göz ve dişin dışındaki diğer organlar zikredilmemektedir. Rabbilere göre burada söz konusu edilen organların ortak yanı vücudun aslî uzuvları olmaları ve kayıpları halinde telafi veya tedavilerinin mümkün olmamasıdır. Çıkış Kitabındaki bu iki cümle (21/26-27)

54 Towner, ,"Hermeneutical Systems ...," s. 118; Elon, "Interpretation”, s. 820.

55 Towner, "Hermeneutical Systems ...," s. 118-119.

56 Towner, "Hermeneutical Systems ...", s. 119; Kuralla ilgili başka örnek için ayrıca bk. Louis Jacobs- David Derovan, "Hermeneutics", s.26; Sifra, Baraita deRabbi Yişmael, 3a-3b.

57 Towner, "Hermeneutical Systems ..., s. 119-120

58 Çıkış Kitabı 21/26-27: "Bir adam erkek ya da kadın kölesini gözüne vurarak kör ederse, gözüne karşlık onu özgür bırakacaktır. Eğer erkek ya da kadın kölesinin dişini kırarsa, dişine karşılık onu özgür bırakacaktır.” 
ışı̆̆ında rabbiler genel bir kural olarak bir efendinin kölesinin bir organını sakatlaması durumunda kölenin azadının gerektiğine hükmetmişlerdir. ${ }^{59}$

\section{4- Kelal u-Perat (כלל ופרט):}

Türkçe’ye “Genel ve Özel” şeklinde çevrilebilecek bu yorumlama kuralı ile İslam hukukundaki Umum ve Husus, Mutlak ve Mukayyed'in benzerliği vardır. Bu kurala kısaca "genelin özel ile sınırlandırılması" diyebiliriz. Kuralın örneklerine Tora'da ve Talmud'da sıkça rastlamak mümkündür. Mesela Levililer Kitabı 1/2'de "İsrailoğullarina söyle ve onlara de: Sizden biri Rabbe kurban arzettiği zaman, kurbanınızı hayvanlardan, sı̆̆ır ve davardan arz edeceksiniz" pasuğunda genel hayvanlardan "ha-behema" (הבהמה) siğır "ha-bakar" (הבקר) ve davar "ha-tson" (הצאן) özel olarak kastedilmiş ve umumî olan bir şey hususi olana tahsis edilmiştir. ${ }^{60}$

Bu metinde uygulandığı şekliyle kelal u-perat argümanı şöyle çalışır:

1. Aşama: TaNaH’ın bir cümlesi "genel ifade” (kelal) olarak tanımlanır. “...kurbanınız hayvanlardan" genel bir ifadedir.

2. Aşama: TaNaH yasasının sonradan gelen bir cümlesi özel (perat) ya da genel ifadenin niteleyicisi olarak verilir. “...sı̆̆ır ve davarlardan...” özel bir ifadedir.

3. Aşama: Kural uygulanarak yorumlama işlem yapılır. Genel bir ifadeyi özel bir ifade izlerse o, özelde ifade edilen kapsamdan daha fazlasını ihtiva etmez.

\section{5- Perat u-Kelal (פרת וכלל):}

“Özel ve Genel” anlamına gelen bu kural bir önceki kuralın aksine, özel olandan genel olana doğru hükmü umumî kılmayı, genişletmeyi amaçlar. Mesela Çıkış Kitabı 22/10 "Şayet bir adam komşusuna eşek "hamor" (חמור) ya öküz "şor" (שור) yahut koyunu "seh" (שה) veya herhangi bir hayvanı verse ve koruması için verdiği bu hayvan kimse görmeksizin ölse yahut sakatlansa veyahut gaspedilse..." ifadesinde cümlede zikri geçen eşek, öküz ve koyun sonrasinda "kol ha-behama" (וְכל-הבְּהָמָ) (herhangi bir/tüm hayvan) ifadesiyle bütün evcil hayvanları kapsayacak genel anlamı vermesi, özelden genele doğru yorumlama kuralına ve böylece hükmü genişletmeye örnek teşkil eder. ${ }^{61}$

\section{6- Kelal u-Perat u-Kelal i-Ata Dan ele ke-Ayn ha-Perat:}

(כלל ופרט וכלל אי אתה דן אלא כעין הפרט):

"Sen ancak hususîleştirilen meselelere dair şeyler hakkında benzer olanlardan hareketle hüküm çıkarabilirsin” şeklinde ifade edebileceğimiz bu kural için Tesniye Kitabı 14/26'da: "Ve parayı (gümüşü) canının dilediği her şey için (kelal= בכל אשר-תאוה נפשך) siğır, koyun, şarap veya müskirat (sarhoş ediciler) için (perat= בבקר ובצאן , וביין ובכשכר) ve canının istediği her şey için (kelal=נובכל אשר תשאלך, vereceksin ve orada, Rabbin Allahin önünde

59 Handelman, The Slayers of Moses, s. 59

60 Sifra, Baraita deRabbi Yişma'el, 4; Toprak, Talmud ve Hadis, s. 242-243; Mielziner, Introduction to the Talmud ..., s. 164-165; Elon, "Interpretation", s. 819; Jacobs-Derovan, "Hermeneutics", s. 27.

61 Sifra, Baraita deRabbi Yişmael, 5; Ayrıca bk. Mielziner, Introduction to the Talmud ..., s. 165; Towner, "Hermeneutical Systems ..., s. 121-122. 
yiyeceksin ve sen ve evinin halkı sevineceksiniz" cümlesini örnek olarak zikredebiliriz. Burada önce genel ifade, sonra özel ifade, devamında yine genel ifade yer almaktadır. ${ }^{62}$

Pasuğun ele aldığı kural, orta bölümdeki "perat, özel” (פרט) kısmında belirtilenlerle ortak yanlara sahip diğer şeyler için de geçerlidir. Başlangıçta kapsamlı olan ifade verildiğinde (Ve parayı -gümüşü- canının dilediği her şey için) "her şey" bu kurala dâhilmiş şeklinde bir yargı belirse de cümlenin devamında bu kuralın detayları (sığır, koyun, şarap veya müskirat -sarhoş ediciler- için) verilince bu sefer de kuralın sadece sayılanlar için geçerli olduğu izlenimini verir. Ancak cümlenin son kısmında "genel" bir ifade kullanılarak (ve canının istediği her şsey için) öncesinde özel olarak zikredilenlere benzeyen her şeyin bu kurala dâhil olduğuna dikkat çekilir. ${ }^{63}$

\section{7- Kelal şe-hu Tsarih li-Perat u-Perat şe-hu Tsarih li-Kelal:}

(כלל שהוא צריך לפרט ופרט שהוא צריך לכלל):

Bu kural "husus (mukayyed) olanı gerektiren umûm ve umûm olanı gerektiren husus", veya "özel" in açıklamasına ihtiyaç duyan "genel", 'ya da tam ve net bir anlamı açıklamak için "genel"in ilavesine ihtiyaç duyan "özel” şeklinde ifade edilebilir. Bu kurala göre; müphem, genel bir kavram, umûmi bir kaide olarak işleyemeyeceği gibi, açıklanmayan husus (özel durum) ifade eden bir terim de husûsî bir kural olarak kabul edilmemelidir. Mesela Levililer Kitabı 17/13'te "İsrail halkından ya da aralarında yaşayan yabancilardan kim eti yenen bir hayvan ya da bir kuş avlarsa kanını akıtıp toprakla örtecektir." denmektedir. Burada "örtecektir" anlamina gelen "ve kissahu" (וכסהו) ifadesi genel olup devaminda "toprakla" anlamına gelen "beafar" (בעפר) ifadesi kuralın "özel” kısmına karşıllk gelmektedir. Ancak "kissa" (כסה) kelimesi "kaplama, örtme, sarma, kuşatma, gizleme" gibi pek çok farklı anlama gelebilen muğlak bir ifadedir. Devamındaki "beafar" (בעפר) ifadesi olmaksızın yasanın sadece bu durumdaki kanları bir tür kapatma malzemesi ile göz önünden kaldırılması ya da görülmemesinin sağlanması şeklinde anlaşılabiliyorken bu özel açıklama ile birlikte bu tür kanların toprak ya da benzeri malzemeyle üstünün örtülmesi şeklinde anlaşılması gerektiği sonucuna varılmaktadır. Ayrıca cümledeki ifadenin "beafar" (בעפר) kısmı da ilk kısımdaki genel anlamlı "vekissahu" (וכסהו) kelimesi olmaksızın toprakla ne yapılacağı ile ilgili belirsizlik dolayısıyla eksik kalacaktır. Bu sebeple örnek cümledeki kelimeler, cümlenin tam anlaşılması için birbirlerine ihtiyaç duymaktadır. ${ }^{64}$

\section{8- Kol Davar şe-Haya be-Kelal ve-Yatsa min ha-Kelal le-Lamed lo le-Lamed al Ats-} mo Yatsa ella le-Lamed al-ha-Kelal kulo Yatsa:

(כל שהיה דבר בכלל ויצא מן הכלל ללמד לא ללמד על עצמו יצא (אלא ללמד על הכלל כלו יצא":

"Şayet genel bir kaideye ait özel bir hadise, istisnaî şekilde takyid ve tahsis edilmişse, bu durumda söz konusu bu hadise, umûmî kuralın ihtiva ettiği bütün vakalara uygulanabileceği

62 Sifra, Baraita deRabbi Yişmael, 6; Ayrıca bk. Mielziner, Introduction to the Talmud ..., s. 167; Jacobs-Derovan, "Hermeneutics", s. 27.

63 Toprak, Talmud ve Hadis, s. 244; Ayrıca bk. Rosensweig, “The Hermeneutic Principles and Their Application", s. 62; Ben David, "Rules of Jewish Hermeneutics", s. 5-6.

64 Mielziner, Introduction to the Talmud ..., s. 169-170: Toprak, Talmud ve Hadis, s. 244-245; Rosensweig, "The Hermeneutic Principles and Their Application", s. 64; Ben David, "Rules of Jewish Hermeneutics", s. 6; JacobsDerovan, "Hermeneutics", s. 27. 
kural olarak kabul edilmelidir.” şeklinde tercüme ve ifade edebileceğimiz bu kurala örnek olarak şunu zikredebiliriz:

a- Çıkış Kitabı 22/17'de genel kural olarak “Büyücü kadını yaşatmayacaksınız.” hükmü vardir.

b- Levililer Kitabı 19/31'de “Cincilere, ruh çă̆ıranlara yönelmeyin, onlara danışmayın, kirlenirsiniz." denilmektedir.

c- Levililer Kitabı 20/27'de "Medyumluk ve üfürükçülükle uğraşan herhangi bir erkek ya da kadın, mutlaka taşlanarak (recm) öldürüleceklerdir; bundan kendileri sorumludur" ifadesi yer almaktadir.

d- Tesniye Kitabı 18/9-11 cümlelerinde yer alan falcılık, büyücülük, kehanetlere göre davranma, sihirli sözler kullanan, medyumluk ve üfürükçülük yöntemleriyle iştigal eden veya ölülere danışan kimseler Tanrı katında büyük bir suç işlemiş olmalarından dolayı kirlenmiş kabul edilir. 12. cümlede Tanrının bu kimselerden tiksineceği ifade edilir.

Bütün bunların ışı̆̆ında kehanet türündeki bütün ameller kötülük açısından aynı kabul edilerek kıyas yoluyla 'benzer suçlara benzer cezalar verilir' hükmüne ulaşılarak genel kuralın kapsamı içerisine giren tüm diğer hadiselerin, benzer ceza gerektireceği şeklinde genel bir hüküm ortaya konur. ${ }^{65}$

\section{9- Kol Davar şe-Haya be-Kelal ve-Yatsa Lit'on To'en Ehad şe-hu ke-İnyano Yatsa Lehakel ve-lo-Lehahmir:}

(כל דבר שהיה בכלל ויצא לטעון טוען אחד שהוא כענינו יצא להקל ולא להחמיר):

Bu kurala göre "Umumi bir yasanın kapsamındaki hususi konular, umumî hükme benzer bir hükümle açıkça ifade edilirse böyle bir durumda söz konusu kuralın kısıtlama-zorlaştırma ve daraltılması değil, sadece genel kuralın hafifletilmesi-kolaylaştırılması sağlanır." 66

Çıkış Kitabı 35/2-3’te şu ifadeler geçmektedir: “Altı gün çalışacaksınız, ama yedinci gün sizin için kutsal Şabat, Rabbe adanmış dinlenme günü olacaktır. O gün çalışan herkes öldürülecektir. Şabat günü evlerinizde ateş yakmayacaksınız.”. Ancak “...Şabat günü evlerinizde ateş yakmayacaksınız...” cümlesinde yer alan ateş yakma yasağı, Şabat gününde çalışma yasağı içerisinde özel olarak zikredilmiştir. Bu durum önceki cümlede yer alan sert cezadan sonra zikredilmesi sebebiyle büyük bir günah olarak görülmekle birlikte cezası önceki cümlede zikredilenden (ölüm cezası) daha hafif olduğuna hükmedilmiştir. ${ }^{67}$

65 Sifra, Baraita deRabbi Yişmael, 8; Toprak, Talmud ve Hadis, s. 245-246; Ayrıca bk. Mielziner, Introduction to the Talmud ..., s. 170; Ben David, "Rules of Jewish Hermeneutics", s. 6-7; Jacobs-Derovan, "Hermeneutics", s. 27.

66 Mielziner, Introduction to the Talmud ..., s. 171-172; Ayrıca bk. Jacobs-Derovan, "Hermeneutics", s. 27; Toprak, Talmud ve Hadis, s. 246; Ben David, "Rules of Jewish Hermeneutics", s. 7; Farklı örnek için bk. Sifra, Baraita deRabbi Yişmael, 9.

67 Toprak, Talmud ve Hadis, s.246; Ben David, "Rules of Jewish Hermeneutics", s. 7; Farklı örnek için bk. Sifra, Baraita deRabbi Yişmael, 9. 


\section{0- Kol Davar şe-Haya bi-Kelal ve Yatsa Lit'on To'an Aher şe-lo ke-İnyano Yatsa Lehakel ve-Lehahmir:}

(כל דבר שהיה בכלל ויצא לטעון טוען אחר שלא כענינו יצא להקל ולהחמיר):

"Ayrıntılarında umumi kurala dâhil edilen hususlara benzemeyen umumî bir kurala dair bireysel olaylar, hususi olarak mukayyed işlem gördügünde, zikredilen kuralın hem kısıtlama ve daraltılması hem de hafifletilmesi ve kolaylaştırılması bu türden aynı olaylara uygulanmalıdır." ${ }^{8}$ şeklinde ifade edilebilir. Bu kurala örnek olarak "bir boğanın bir kişiyi boynuz darbesiyle öldürme sonucunda boğa ve sahibi ile ilgili cezâi hükümlerin ne olacağı" hususunda Çıkış Kitabı 21/28-32'de yer alan şu cümleler zikredilebilir:

a- 28. Cümle, (Sahibin olaydan haberdar olmaması durumu): "Eğer bir boğa bir erkeği ya da kadın boynuzuyla vurup öldürürse, kesinlikle taşlanacak ve eti yenmeyecektir. Boğanın sahibi ise suçsuz sayılacaktır."

b-, 29-31. Cümleler, (Sahibin uyarılmış olması ve gerekli tedbiri almadığı durum): "Ama saldırganlı̆̆ bilinen bir boğanın sahibi uyarılmasına karşın boğasına sahip çıkmazsa ve boğası bir erkeği ya da kadını öldürürse, hem boğa taşlanacak, hem de sahibi öldürülecektir. Ancak boğanın sahibinden para cezası istenirse, istenen miktarı ödeyerek canın kurtarabilir. Boğa ister erkek, ister kız çocuğunu öldürsün, ayn kural uygulanacaktır."

c- 32. Cümle: (Mağdurun köle olması durumu): "Eğer boğa bir erkek ya da kadın köleyi öldürürse, kölenin efendisine otuz şekel gümüs verilecek ve boğa taşlanacaktır." Burada son kısımda zikredilen fidye hükmü, umumî kural içerisinde ayrıca aktarılmıştır. ${ }^{69}$

11- Kol Davar şe-Haya bi-Kelal ve Yatsa min ha-Kelal Lidon ba-Davar ha-Hadaș i-Ata Mahziro li-Kelalo ad şe-Yahazirennu ha-Katuv li-Kelalo be-Peruş:

כל דבר שהיה בכלל ויצא מן הכלל לדון בדבר החדש אי אתה מחזירו לכללו עד שיחזירנו הכתוב) (לכללו בפרוש):

"Genel bir hükümle ilgili özel bir durum, tamamen yeni bir koşulla genelden hariç tutulduğunda, Tora bu durumu özel kılmadığı müddetçe, özel kuralın detayları bu münferid olaya uygulanmalıdır"70 şeklinde Türkçeye çevirebileceğimiz bu kurala örnek olarak bazı takdimelerin yer aldığı Levililer Kitabı 14/11-20 cümlelerini zikredebiliriz. Bu cümlelerde günah-takdimelerinin kanının Mezbah’a serpileceği, ancak temizlenen cüzzamlının takdimesi istisna olarak hükmün dışında tutularak, günah-takdimesinin kanı temizlenen kişinin sağ kulak kıkırdağına, sağ el ve sağ ayak başparmağına sürülmüştür. Söz konusu kurbanın günah-takdimesiyle ilgili genel kuraldan ayrı değerlendirilmesi ve takdime kanının serpilmesiyle ilgili yeni bir uygulama anlatması yeni bir hükümdür. ${ }^{71}$

68 Toprak, Talmud ve Hadis, s. 247; Mielziner, Introduction to the Talmud ..., s. 172; Ben David, "Rules of Jewish Hermeneutics", s. 7-8.

69 Toprak, Talmud ve Hadis, s. 247; Mielziner, Introduction to the Talmud ..., s. 172; Ben David, "Rules of Jewish Hermeneutics", s. 7-8; Farklı örnek için bk. Sifra, Baraita deRabbi Yişmael, 10; Jacobs-Derovan, "Hermeneutics", s. 27.

70 Toprak, Talmud ve Hadis, s. 253-254; Mielziner, Introduction to the Talmud ..., s. 173.

71 Sifra, Baraita deRabbi Yişmael, 11; Ayrıca bk. Jacobs-Devoran, "Hermeneutics", 27; Toprak, Talmud ve Hadis, s. 253254; Mielziner, Introduction to the Talmud ..., s. 173; Ben David, "Rules of Jewish Hermeneutics", s. 8. 


\section{2- Davar ha-Lamed me-İnyano ve-Davar ha-Lamed mi-Sofo:}

(דבר הלמד מענינו ודבר הלמד מסופו):

"Bir yasanın ya da yasada yer alan kelimenin tam anlamı ya siyâk ve sibakından; ya aynı pasaj, cümlede daha sonra gelecek bir atıftan hareketle sözün gidişatından; ya da manası müphem bir kelimenin kendi bağlamı içerisindeki kullanımından hareketle izah edilebilir" anlamına gelir. ${ }^{72}$

Levililer Kitabı 11/13-19'da eti helal olmayan kuşlar anlatılmaktadır: "Tiksindirici kuşların etini yemeyecek, şunları iğrenç sayacaksınız: Kartal, kuzu kartal, kara akbaba, çaylak, doğan türleri, bütün karga türleri, baykuş, puhu, martı, atmaca türleri, kukumav, karabatak, büyük baykuş, peçeli baykuş, ishakkuşu, akbaba, leylek, balıkçıl türleri, ibibik, yarasa.”

Levililer Kitabı 29-30. cümlelerde ise temiz kabul edilmeyen sürüngenler sayılmaktadır: "Küçük kara hayvanları içinde sizin için kirli sayılanlar şunlardır: Gelincik, fare, bütün kertenkele türleri -geko, varan, duvar kertenkelesi, düz keler-bukalemun.”.

Burada her iki gruptaki hayvanlar sıralanırken "ha-tinşemet" (התנשמת) kelimesi kullanılmaktadır. Zikredilen cümleler bu kurala göre ele alındığında 13-19. cümlelerde ilk k1sımda kuş türleri sayıldığından kelimenin “peçeli baykuş”; 29-30. cümledeki kullanımda ise siyak sibaka bakıldığında sürüngenler sıralandığı için burada "köstebek" anlamında kullanıldığı ifade edilmiştir. ${ }^{73}$

\section{3- Şney Ketuvim ha-Makhişim ze et ze ad şe-Yavo ha-Katuv ha-Şelişi ve-Yakri’a Beyneyhem:}

(שני כתובים מכחישים זה את זה עד שיבוא השלישי ויכריע ביניהם):

"Çelişik gibi duran iki metnin üçüncü bir metnin yardımı ile birbirleriyle uyumlu hale getirilebilir" şeklinde ifade edilebilir. Örnek olarak şu cümleleri zikredebiliriz:

a- Çıkış Kitabı 13/6'da “Yedi gün mayasız ekmek yiyecek, yedinci gün Rab’be bayram yapacaksınız" denilmektedir.

b- Tesniye Kitabı 16/8'de “Altı gün mayasız ekmek yiyeceksiniz...” ifadesi önceki cümleyle çelişik gibi durmaktadır.

c- Levililer Kitabı 23/14'de ilk ürün hasadı ile ilgili gerçekleştirilen "omer" takdimesi hakkında "Tanrınız’a bu sunuyu getireceğiniz güne kadar ekmek, kavrulmuş buğday, taze başak yemeyeceksiniz...” denmektedir. Buradan hareketle yeni üründen hazırlanan mayasız ekmek yalnızca bu bayramın geri kalan altı günüde yenilmesi gerektiği ifade edilerek ilk iki cümleyle ilgili çelişki giderilmeye çalışılmıştır. ${ }^{74}$

72 Sifra, Baraita deRabbi Yişmael, 12a-12b; Toprak, Talmud ve Hadis, s. 253-254; Mielziner, Introduction to the Talmud ..., s. 174 .

73 Sifra, Baraita deRabbi Yișmael, 12a-12b; Mielziner, Introduction to the Talmud ..., s. 174; Konu ile ilgili bașka örnekler için ayrıca bk. Toprak, Talmud ve Hadis, s. 253-254; Ben David, "Rules of Jewish Hermeneutics", s. 8; Elon, "Interpretation", s. 819; Strack-Stemberger, Introduction to the Talmud and Midrash, s. 23; Towner, "Hermeneutical Systems ..., s. 124.

74 Sifra, Baraita deRabbi Yişmael, 13; Mielziner, Introduction to the Talmud ..., s. 175-176; Konu ile ilgili başka örnekler için ayrıca bk. Towner, "Hermeneutical Systems ...”, s. 126-127; Ben David, "Rules of Jewish Hermeneutics", s.8-9. 
Çeşitli uygulama örnekleriyle genel olarak açıklamaya çalıştı̆̆ımız R. Yişmael'in bu kuralları ile ilgili modern dönemde çok farklı çalıșmalar yapılmıștır. Amerika hukukundan bazı uygulama örnekleri ile özellikle Kal va-Homer, Gezera Şave, Davar ha-Lamed meİnyano / mi-Sofo gibi kuralların mukayeseli olarak verilerek Hıristiyan, İslam, Grek-Roma ve bazı Hint kaynaklarından çeşitli örneklerin sunulduğu çalışmayı örnek olarak zikredebiliriz. $^{75}$

\section{Sonuç:}

İkinci Mabet sonrası dönemin Yahudilik anlayışı diyebileceğimiz Rabbâni Yahudilikte tüm dini faaliyetlerin merkezinde Yahudi Kutsal Kitabı $(\mathrm{TaNaH})$ yer almaktadır. Rabbâni Yahudiliğe göre Sina vahyinin muhtevası içerisinde kutsal kitaba ilaveten kutsal kitabın yorumları ve bu yorumlara dayanak teşkil eden yorum kuralları (middot) da yer aldığından bu vahiy anlayışı tüm bu zikredilen alanlara ilahi bir nitelik kazandırmayı sağlamaktadır. Buna paralel olarak Rabbâni Yahudilikte R. Yişmael'in on üç yorum kuralına, kendisinden önce gelmiş olan Hillel'in yedi yorum kuralı gibi büyük ehemmiyet verilmiştir.

Her ne kadar Yahudi geleneği içerisinde ilahi vahyin bir parçası olarak algılansa da, Yişmael, Hillel gibi rabbilerin bu kuralların bizzat mucitleri olması bir tarafa, kendilerine izafe edilen listelerde yer alan kuralların tamamını kutsal kitapla ilgili yorumlarında uygulayıp uygulamadıkları bile tartışmalıdır. Bu kuralların Helenistik düşünce dünyası başta olmak üzere yabancı kültürlerin etkilerini yansıttığını iddia eden araştırmacılar da bulunmaktadır. Ancak daha önce de ifade edildiği gibi Yahudiler genellikle bu listelerin otantikliği veya bizzat izafe edildikleri din bilginleri tarafından oluşturulduklarından şüphe duymamaktadırlar. Bu doğrultuda R. Yişmael'in yorum kuralları, kendisinden önce Hillel tarafından oluşturulmuş olan yedi kuraldan müteșekkil listenin daha gelişmiş biçimini temsil etmektedir. Bu yönüyle R. Yişmaelin kuralları Rabbâni dönem yorumunun omurgası mesabesinde görülebileceği gibi kendisinden sonra gelen R. Eliezer b. Yose ha-Galili’nin otuz iki yorum kuralı için de örnek ve öncü olarak değerlendirilebilir.

75 Daniel A. Klein, “Rabbi Ishmael, Meet Jaimini: The Thirteen Middot of Interpretation in the Light of Comparative Law”, Hakirah 16 (2013): s. 91-112, www.hakirah.org/Vol\%2016\%20Klein.pdf, (Erişim Tarihi: 05.06.2015) 


\section{Kaynaklar}

Araz, Ömer Faruk, Yahudilikte Midraşik Literatürün Tarihsel Gelişimi, Basılmamış Doktora Tezi, Marmara Üniversitesi SBE, İstanbul, 2016. , “Rabbani Yahudiliğin İlk Yorum Prensipleri: Hillel'in Yedi Yorum Kuralı”, Insan ve Toplum Bilimleri Araştırmaları Dergisi, c.5, sayı 2, 2016, s.321-337.

Bacher, Wilhelm, “Hillel”, JE, VI, 397-399.

Ben David, Hillel (Greg Killian), "Rules of Jewish Hermeneutics", s.1-4, http://www.betemunah.org/rules.html, (Erişim Tarihi: 04.06.2015).

Bokser, Baruch M., “Amoraim”, ER, I, 294-295.

Brown, Francis ve S.R. Driver, C.A. Briggs, Hebrew and English Lexicon of The Old Testament, New York: The Riverside Press, 1906.

Broydé, Isaac, “Rabbi”, JE, X, 294.

Chan, Man Ki, A Comparative Study Of Jewish Commentaries And Patristic Literature On The Book Of Ruth, Yayınlanmamış Doktora Tezi, University of Pretoria, Faculty of Theology, Department of Old Testament Studies, 2010.

Cohen, Shaye J. D., “The Judean Legal Tradition and the Halakhah of the Mishnah", The Cambridge Companion to The Talmud and Rabbinic Literature, (ed.) Charlotte Elisheva Fonrobert, Martin S. Jaffee, New York: Cambridge Un. Press, 2007, 121-143.

Daube, David, "Rabbinic Methods of Interpretation and Hellenistic Rhetoric", HUCA, 22 (1949), 239-264.

Davies, Philip R., "Judaism and the Hebrew Scriptures", (ed.) Jacob Neusner and Alan Avery-Peck, The Blackwell Companion to Judaism, USA: Blackwell Publishing Ltd., 2004, 37-57.

Elon, Menahem, “Interpretation”, EJd', IX, 814-827.

Epstein, Isidore, “Foreword”, Midrash Rabbah, (ed.) H. Friedman, M. Simon, London: The Soncino Press, 1939.

Fishbane, Michael, The Garments of Torah: Essays in Biblical Hermeneutics, USA: Indiana University Press, 1992.

Fraade, Steven D., “The Early Rabbinic Sage”, The Sage in Israel and the Ancient Near East, (ed.) John G. Gammie and Leo G. Perdue, İndiana: 1990, s. 417-436.

Frankel, Israel, Peshat in Talmudic and Midrashic Literature, Toronto: La Salle Press, 1956.

Gertner, M., “Terms of Scriptural Interpretation: A Study in Hebrew Semantics”, Bulletin of the School of Oriental and African Studies 25, No.1/3 (1962), s. 1-27.

Glatzer, Nahum N., Hillel the Elder: The Emergence of Classical Judaism, New York: Schocken Books, 1956.

Goldin, Judah, "Hillel the Elder", The Journal of Religion, vol.26, no.4 (Oct., 1946), 263-277. 
Gray, Alyssa M., “Amoraim”, EJd², II, 89-94.

Guttman, Alexander, Rabbinic Judaism in the Making, Detroit: Wayne State Univ. Press, 1970.

Handelman, Susan A., The Slayers of Moses, The Emergence of Rabbinic Interpretation in Modern Literary Theory, New York: State Un. Of New York Press, Albany, 1982.

Harman, Ömer Faruk, "Ahd-i Atik", DİA, I, 494-501.

,"Yahudilik", DİA, XLIII, 197-201.

Horowitz, Yehoshua, "Hillel”, EJd', IX, 108-110.

Jacobs, Joseph. “Cohen”, JE, IV, 144.

Jacobs, Louis, “Judaism”, EJd², XI, 511-520.

Jacobs, Louis - David Derovan, "Hermeneutics", EJd², IX, 25-29.

Klein, Daniel A., "Rabbi Ishmael, Meet Jaimini: The Thirteen Middot of Interpretation in the Light of Comparative Law", Hakirah 16 (2013): s. 91-112, www.hakirah.org/ Vol\%2016\%20Klein.pdf, (Erişim Tarihi: 05.06.2015).

Kugel, James L., Traditions of the Bible: A Guide to the Bible As It Was at the Start of the Common Era, USA: Harvard Un. Press,1999.

Lauterbach, Jacob Zallel, “Zugot”, JE, XII, 698.

, “Tannaim and Amoraim", JE, XII, 49.

Lieberman, Saul, "Rabbinic Interpretation on Scripture", Hellenism in Jewish Palestine: Studies in the Literary Transmission, Beliefs and Manners of Palestine in the I Century $B C E-I V$ Century CE, 2. bs., New York: Jewish Theological Seminary of America, 1962, s. 47-82.

Mielziner, Moses, Introduction to the Talmud: Historical and Literary Introduction, Cincinnati and Chicago: Bloch Printing Company, 1894.

Najman, Hindy, Seconding Sinai: The Development of Mosaic Discourse in Second Temple Judaism, Boston, USA: Brill, Leiden, 2003.

Neusner, Jacob, Invitation to Midrash, USA: Atlanta Scholar Press 1998.

,"Midrash and the Oral Tora: What Did the Rabbinic Sages Mean by 'The Oral Tora", The Encyclopaedia of Judaism, ed. J. Neusner v.dğr., Netherlands: Brill 2005, III, 17071708.

, The Rabbinic Traditions About The Pharisees Before 70, Leiden: Brill, 1971, I-III.

,"The History of Earlier Rabbinic Judaism: Some New Approaches", History of Religions, 16:3 (1977: Feb), 216-236.

Newman, Jacob, Halakik Sources: From the Beginning to the Ninth Century, Leiden: E.J. Brill, 1969. 
Oeming, Manfred, Biblical Hermeneutics: An Introduction, terc. Joachim F. Vette, England: Ashgate, 2006, s.9-11.

Pirke Avot, Rav Naftali Haleva (terc.), İstanbul: Gözlem Yayıncılık, 2004.

Porton, Gary G., "Rabbinic Midrash”, Judaism in Late Antiquity Part I The Literary \& Archaelogical Sources, ed. Jacob Neusner, Leiden: E. J. Brill, 1995.

Rabinowitz, Louis Isaac, "Rabbi, Rabbinate”, EJd', XVII, 11.

Rosensweig, Bernard, “The Hermeneutic Principles and Their Application”, Tradıtıon: A Journal of Ortodox Thought, vol.13, no.1 (Summer 1972), 49-76.

Schechter, Solomon - S. Mendelsohn, “Eliezer ben Jose ha-Gelili”, JE, V, 117.

Schiffmann, Lawrence H., From Text to Tradition: A History of Second Temple and Rabbinic Judaism, New Jersey: Ktav Publishing House Inc., Hoboken, 1991.

Schürer, Emil ve Geza Vermes v.dğr.(ed.), The History of the Jewish People in the Age of Jesus Christ (175 B.C. - A. D. 135), Edinburg: T\&T Clark Ltd., 1979.

Sifra, Baraita deRabbi Yişmael 1, 1-17. (Erişim Tarihi: 20.02.2016), http://www.sefaria.org/ Sifra, Braita_d'Rabbi_Yishmael.2?lang=he-en\&layout=heLeft\&sidebarLang=all.

Sinanoğlu, Mustafa, “Eski Ahid ve Kur’an-1 Kerim’de Sina Vahyi”, İslam Araştırmaları Dergisi, 2 (1998), s. 1-22.

Sperber, Daniel. “Tannaim” EJd', XIX, 505.

Steinschneider, Moritz, Jewish Literature from the Eighth to the Eighteenth Century: with an Introduction on Talmud and Midrash, terc. William Shotliswoode, London: Longman, Brown, Green, Longmans, \& Roberts, 1857.

Strack, H.L. ve G. Stemberger, Introduction to the Talmud and Midrash, terc. Marcus Bockmuehl, Edinburg: T \& T Clark, 1991.

Toprak, Mehmet Sait, Talmud ve Hadis, İstanbul: Kabalcı Yayınc1lık, 2012.

Towner, W.Sibley, "Hermeneutical Systems of Hillel and the Tannaim: A Fresh Look”, Hebrew Union College Annual 53 (1982), s. 101-135.

Urbach, Ephraim E., The Sages Their Concepts and Beliefs, Jerusalem: Magnes Press, 1975, I-II.

Wald, Stephen G., “Aggadah or Haggadah” EJd', I, 454.

Wald, Stephen G., “Mishnah” EJd², XIV, 319-331.

* Bu çalışmanın düşünce aşamasından, en ham halindeki notlarının gözden geçirilmesine ve nihayetinde ete-kemiğe bürünmüş bu haline erişmesine kadar bütün süreçlerinde, sorduğu sorulardan yaptığı değerlendirme, yönlendirme ve tashihlere, her türden kıymetli katkıları için hocam Prof. Dr. İsmail Kara'ya medyun-1 şükran olduğumu ifade etmeliyim.

** Araştırma Görevlisi, Marmara Üniversitesi İlahiyat Fakültesi, gullu.yildiz@marmara.edu.tr 
Zaqantov, Jochanan, "Plain Meaning and Analogy, Peshat ve Heqqesh", 1-14,

http://www.karaitejudaism.org/talks/Plain_Meaning_and_Analogy.pdf, (Erişim Tarihi: 15.09.2015).

Zeitlin, Solomon, "Hillel and the Hermeneutic Rules", JQR, New Series, Vol.54, No.2 (Oct., 1963), s. 161-173. 